\title{
Why People Waive Their Miranda Rights: The Power of Innocence
}

\author{
Saul M. Kassin ${ }^{1,3}$ and Rebecca J. Norwick ${ }^{2}$
}

In a laboratory experiment, 72 participants who were guilty or innocent of a mock theft were apprehended for investigation. Motivated to avoid prosecution and trial, they were confronted by a neutral, sympathetic, or hostile male "detective" who sought a waiver of their Miranda rights. Later, 72 other participants watched videotapes of these sessions and answered questions about the detective and suspect. Strikingly, results showed that although the detective's demeanor had no effect, participants who were truly innocent were significantly more likely to sign a waiver than those who were guilty. Naively believing in the power of their innocence to set them free, most waived their rights even in the hostile detective condition, where the risk of interrogation was apparent. The conceptual and policy implications of these results are discussed.

KEY WORDS: Miranda, interrogation, confessions, waiver, innocence.

In the landmark case of Miranda v. Arizona (1966), the U.S. Supreme Court ruled that police must inform all suspects in custody of their Constitutional rights to silence and to counsel. A number of subsequent rulings carved out exceptions to this rule and limited the consequences for noncompliance. In New York v. Quarles (1984), for example, the Supreme Court argued that "overriding considerations of public safety" could justify a violation of the requirement. In Harris v. New York (1971), and again in Oregon v. Hass (1975) and Michigan v. Harvey (1990), the Court ruled that although a statement taken in violation of Miranda cannot be used in the state's case in chief, it is admissible at trial to impeach a defendant's testimony. These developments have led legal scholars to question the extent to which police are free to disregard Miranda (Clymer, 2002; White, 2001).

In a vitally important symbolic decision, the Supreme Court recently upheld the basic warning-and-waiver requirement in the case of Dickerson v. United States (2000). In some respects, however, the requirement may prove to be a moot point

\footnotetext{
${ }^{1}$ Department of Psychology, Williams College, Williamstown, Massachusetts.

${ }^{2}$ Department of Psychology, Harvard University, Cambridge, Massachusetts.

${ }^{3}$ To whom correspondence should be addressed at Department of Psychology, Williams College, Williamstown, Massachusetts 01267; e-mail: skassin@williams.edu.
} 
(Leo, 2001; White, 2001). Arguing that modern criminal interrogations are inherently coercive and that procedural safeguards are a necessary means of protection, the Supreme Court, in Miranda, had ruled that police must advise suspects who are in custody that: "You have the right to remain silent; anything you say can and will be used against you in a court of law; you have the right to an attorney; if you cannot afford one, one will be provided to you free of charge." At the time, opponents argued vociferously that the requirement would impair law enforcement efforts, but early impact studies indicated that it did not have this effect. In addition, research shows that juvenile suspects do not fully comprehend or know how to apply the rights they are given (Grisso, 1981, 1998). The same is true of adult defendants who are mentally retarded or who are inexperienced within the criminal justice system (Everington \& Fulero, 1999; Fulero \& Everington, 1995).

Today, Miranda is alive again and in dispute (Leo \& Thomas, 1998). On the basis of pre-post studies and international comparisons, critics claim that the confession and conviction rates have dropped dangerously as a direct result of the warning and waiver requirements (Cassell, 1996; Cassell \& Fowles, 1998). Defenders of Miranda argue, however, that the post-1966 declines are small and causally ambiguous (Schulhofer, 1996) and that the protection is needed to combat police coercion (Kamisar, 1995). Importantly, based on naturalistic observations of live and videotaped police interrogations, Leo (1996) reported that four out of five suspects routinely waive the rights they are given and submit to questioning (see also Leo \& White, 1999).

Why do so many people waive their rights? With all that is known about modern police interrogation methods-and the risk that they may elicit false confessions from innocent people (Gudjonsson, 2003; Kassin, 1997; Kassin \& Kiechel, 1996; Leo \& Ofshe, 1998; Radelet, Bedau, \& Putnam, 1992; Wrightsman \& Kassin, 1993; Zimbardo, 1967) - the Miranda waiver is a risky choice for anyone under investigation. One possible reason for the high waiver rate is that police employ techniques designed to obtain waivers just as they do confessions. Indeed, Leo (1996) observed that police investigators often overcome the warning-and-waiver requirement by strategically establishing rapport with the suspect, offering sympathy and an ally, and minimizing the process as a mere formality, thus increasing perceived benefits relative to costs. In addition, police in some jurisdictions, as in California, are specifically trained in how to get suspects to talk "outside Miranda"-even after they have invoked their rights. Statements taken in this manner cannot be used in the state's case in chief at trial. However, such "off the record" disclosures (e.g., as to the whereabouts of physical evidence, names of witnesses, or identities of accomplices) may then be used both to generate other admissible evidence and to impeach the defendant at trial if he or she testifies (Philipsborn, 2001; Weisselberg, 2001).

A second possibility is suggested by individual differences among actual suspects. As previously observed by researchers in Great Britain (Softley, 1980), Leo (1996) found that people who have no prior felony record are far more likely to waive their rights than are those with criminal justice "experience." In light of known recidivism rates in criminal behavior and the corresponding base rate assumption that people without a criminal past are less likely to commit future crimes (Zamble \& Quinsey, 
1997), this difference suggests the hypothesis that innocent people in particular may be at risk to waive their rights.

As the gateway to police interrogation and the production of confessions, which can have far reaching and rippling effects on the disposition of cases (Leo \& Ofshe, 1998), the invocation or waiver of Miranda is a pivotal choice point in the life of the accused and in the criminal justice system. Yet to our knowledge, the psychological factors that influence this decision have never been systematically studied. As a first important step, then, we developed an experimental mock crime-and-investigation paradigm with four goals in mind: (1) to examine the base rate tendency of people to waive their rights; (2) to test the hypothesis that police can increase the waiver rate through the use of sympathy and minimization; (3) to test the converse hypothesis that the waiver rate will be suppressed in people confronted with a hostile and closedminded interrogator; and (4) to examine the role of a suspect's actual guilt and innocence in this decision-making.

\section{METHOD}

\section{Suspects}

A total of 144 introductory psychology students were recruited to participate in exchange for extra course credit. Seventy-two students (32 males and 40 females) were randomly assigned to one of six cells produced by a 2 (Guilty vs. Innocent suspect) $\times 3$ (Neutral, Sympathetic, or Hostile interrogator) factorial design $(n=12$ per cell). Prior to each session, participants read and signed an informed consent statement which included the disclosure that, "For the purpose of this study, I may be asked to commit a mock crime or a related innocent act and undergo an interrogation about the experience."

Upon their arrival, participants were met by a female experimenter who obtained informed consent, addressed concerns and questions, and presented task instructions. Importantly, all were advised that if they find themselves in a difficult interrogation situation, they should do whatever they see as necessary to protect themselves (e.g., "You can choose to talk to the police or not, you can be friendly or you can be hostile, whatever you think will help your cause"). To get participants to model the real-life suspect's focus on long-term consequences, we said that the study may at a later time require a second phase - a "trial" for which additional experimental credit would not be available. They were told, "Whether there is a trial phase will depend on whether there is sufficient evidence that you are guilty. So do what it takes in your long-term best interest to either avoid going to trial or to be acquitted at trial." Pilot testing of this paradigm indicated that students accepted this cover story without suspicion.

At that point, the experimenter handed all participants an envelope containing one of two sets of instructions. The guilty set provided specific directions on how to steal a $\$ 100$ bill from a drawer in a nearby laboratory classroom, whereas the innocent set directed participants merely to open and shut an empty drawer without theft. Those assigned to the guilty condition followed instructions, entering the room alone, opening the drawer, taking the $\$ 100$, folding it in half, putting it into their 
pocket, and shutting the door as they left the room. Those assigned to the innocent condition went through the same motions but did not take or pocket money from a drawer. Afterward, participants met the same condition-blind experimenter who took them upstairs to an interrogation cubicle furnished with wooden table, two chairs, a two-way mirror, and a video camera stationed on a tripod. The sessions were videotaped for subsequent viewing.

All participants were detained in this cubicle for 5-min, after which a middleaged man in civilian clothing came in, introduced himself as Detective McCarthy, and asserted that the participant was under suspicion for money that was recently stolen from the building. The detective-who was "blind" as to each participant's guilt or innocence-said that before discussing the matter, he had to read the participant his or her Miranda rights. At that point, one of three variations was administered. In a neutral condition, the detective read the Miranda warning verbatim without added comment and presented a waiver form to the participant for a decision and signature. In the sympathy-minimization condition, he gently encouraged the participant to relax and offered a drink of water. He described the waiver process as a mere formality and told the participant that although he or she may look guilty, "I think you deserve a chance to tell your side of the story." In the hostile-closed minded condition, the detective angrily prefaced his reading of the rights by saying, "I am sick of this happening. It's not the first time something like this has happened. I know you did this and I don't want to hear any lies from you."

Following one of these presentations, the detective handed participants a waiver form and pen and instructed them to take time to reread the rights and sign one of the two statements: "I am willing to make a statement and answer questions at this time" or "I am not willing to make a statement or answer questions at this time." Afterward, he asked them if they were sure of the decision they made, thanked them, and left the room. At that point, the experimenter reappeared, told participants that they would not be interrogated, and administered a questionnaire on which they were asked to explain their decision. Participants then rated the believability and stressfulness of the whole experience as well as the amount of effort and pressure the detective had put on them to sign the waiver. All sessions lasted for about $20 \mathrm{~min}$, after which participants were fully debriefed and thanked for their contribution. Those in the guilty condition were then asked to return the $\$ 100$ bill they had taken.

\section{Observers}

To get a nonparticipant's perspective on detective-suspect interactions, each of 72 undergraduate observers (36 males and 36 females) watched the videotape of a single session involving a neutral, sympathetic, or hostile interrogator. As determined at the outset of each session, observers had no prior knowledge of the experiment and did not know the student suspect they were assigned to watch. Further, nothing was said of the suspect's actual guilt or innocence.

By random assignment without replacement, all observers were shown one Miranda session up to the point at which the detective presented the waiver form to the suspect. The tape was then paused and observers were asked to predict the 
decision that they would make and the decision the suspect actually made. The rest of the tape was then played, after which observers judged the suspect as guilty or innocent and rated their confidence in that response on a 10-point scale, yielding a judgment score that ranged from -10 (certain innocence) to +10 (certain guilt). Then on separate 10-point scales, they rated how friendly and hostile the detective was, how hard he tried to elicit a waiver, and the extent to which he presumed the suspect to be guilty.

\section{RESULTS}

Postinterrogation questionnaire responses indicated that the action, detention, and interrogation phases of the experiment were moderately believable (overall $\mathrm{Ms}$ for these three measures were $6.08,5.88,6.83$, respectively, on 1-10 point scales) - and the experience as a whole was moderately stressful $(M=5.93$, also on a $1-10$ point scale). There were no differences on these measures as a function of the independent variables.

The key dependent measure was whether participant suspects agreed or refused to waive their rights. Overall, 42 out of 72 suspects (58\%) signed the waiver option. A logistic regression testing the effect of suspect guilt or innocence and interrogation style as predictors of waiver choice against a constant-only model was significant, $\chi^{2}(3, N=72)=16.5, p<.001$. With regard to the hypothesis that the waiver rate would be increased by the sympathetic detective and decreased by the hostile detective, the waiver rates were $58 \%, 63 \%$, and $54 \%$, in the neutral, sympathy, and hostile conditions, respectively. Interrogator style did not meet the Wald criterion in predicting the waiver decision, $z=1.03, n s$. There was, however, a striking effect for guilt or innocence, as $81 \%$ of all innocent suspects waived their rights compared to only $36 \%$ of those who were guilty, $z=4.93, p<.02$. This effect was powerful. Table 1 shows that innocent suspects were more likely than guilty suspects to waive their rights in both the neutral and sympathy conditions, Yates corrected $\chi^{2}(1, N=24)=6.17$ and 8.71 , respectively; both at $p<.01$. Although it was not significant, a similar tendency was found in the hostile-closed minded interrogator condition, $\chi^{2}(1, N=24)=1.51$, $p<.25$. The logistic regression revealed that the interaction of interrogation style and the suspect's guilt or innocence did not significantly predict the waiver decision, $z=1.12, n s$.

To understand why innocent suspects were more likely than guilty suspects to waive their rights, we examined the open-ended explanations they gave for this

Table 1. Percentage of Participants Who Agreed to Waive Their Rights as a Function of Guilt or Innocence and Interrogation Condition

\begin{tabular}{lcccc}
\hline & \multicolumn{4}{c}{ Interrogation condition } \\
\cline { 2 - 5 } Suspect & Neutral & Sympathetic & Hostile & Totals \\
\hline Guilty & 33 & 33 & 42 & $36 \%$ \\
Innocent & 83 & 92 & 67 & $81 \%$ \\
Totals & $58 \%$ & $63 \%$ & $54 \%$ & \\
\hline
\end{tabular}


decision (in pretesting, two types of explanation were given for the waiver-and the agreement rate between two coders was $100 \%$ ). These data revealed clearly the basis for the effect. Specifically, 12 of the 13 guilty suspects who waived their rights articulated strategic self-presentation reasons for the waiver (e.g., "if I didn't, he'd figure I was guilty," "I would've looked suspicious if I chose not to talk"). Although 11 of the 29 innocent waiver suspects offered similar explanations, 21 of them also (8) or instead (13) explained that they waived their rights precisely because they were innocent-believing, apparently, in the power of this truth to prevail (e.g., "I did nothing wrong," "didn't have anything to hide").

Additional questionnaire data suggested a possible reason for why sympathyand-minimization did not significantly increase the waiver rate. On 10-point scales, suspects rated how hard the detective tried to get them to waive their rights and the amount of pressure he put on them to do so. On both measures, a main effect for interrogation condition indicated that relative to those in the neutral control group, those in both the sympathy and hostile conditions perceived the detective as trying harder, $M \mathrm{~s}=4.21 \& 4.04$, respectively, vs. $2.63 ; F(2,66)=4.57, p<.01, \eta_{\mathrm{p}}^{2}=.12$, and felt more pressured to waive their rights, $(M \mathrm{~s}=4.25 \& 4.33$, respectively, vs. $\left.2.83 ; F(2,66)=3.52, p<.05, \eta_{\mathrm{p}}^{2}=.09\right)$. Thus, sympathy-and-minimization may have lacked impact in part because suspects saw it correctly as a technique rather than as indicative of a genuine concern on the part of the detective (there were no other significant effects on these measures).

Observers' perceptions of the situation were particularly instructive. When asked to speculate about how they would react, $46 \%$ said that they would waive their rights in the situation they saw-an estimate that did not vary by condition, $\chi^{2}(1, N=72)$ $<1$. Yet when asked to predict the decision made by the suspect they were watching, $65 \%$ predicted a waiver-an expectation that was greater among those who observed neutral (79\%) and sympathy (71\%) sessions than a hostile interrogator condition $(46 \%) ; \chi^{2}(2, N=72)=4.09, p<.05$. Thus, observers were more likely in general to predict waivers for others than for themselves, $\chi^{2}(1, N=72)=5.51$, $p<.02$, though neither of the estimates differed significantly from the behavior of the actual suspects, $58 \%$ of whom waived their rights (both $\chi^{2}<1$ ).

Perceptions of the interrogator were also instructive, as significant main effects were obtained on ratings of friendliness, $F(1,66)=6.90, p<.002, \eta_{\mathrm{p}}^{2}=.17$, hostility, $F(1,66)=20.59, p<.001, \eta_{\mathrm{p}}^{2}=.37$, presumption of guilt, $F(1,66)=16.25, p<.001$, $\eta_{\mathrm{p}}^{2}=.32$, and effort to elicit a waiver $F(1,66)=12.14, p<.001, \eta_{\mathrm{p}}^{2}=.25$. Post hoc tests revealed that compared to observers who saw a neutral interrogation, those who saw a hostile tape saw the detective as less friendly $(M=3.21$ vs. 5.63$)$, more hostile ( $M=6.25$ vs. 2.25$)$, and more presumptuous of the suspect's guilt ( $M=7.94$ vs. 5.00$)$. Clearly, and despite the suspects' waivers, the danger presented by the hostile and closed-minded interrogator was readily apparent. Perceptions of the detective who used sympathy and minimization were somewhat more complicated. Compared to those who watched a neutral session, observers who saw a sympathy tape saw the detective as more hostile ( $M=3.75$ vs. 2.25$)$, more presumptuous of guilt $(M=7.04$ vs. 5.00), and as trying harder to elicit a waiver $(M=5.67$ vs. 3.04). Consistent with data provided by suspects, then, sympathy and minimization was seen as merely a ploy to elicit a waiver. 
Importantly, recall that most guilty suspects who waived their rights said they did so for self-presentation reasons. To assess the impact of this strategy, we examined the inferences of guilt and innocence drawn by observers, each of whom watched a suspect make a waiver decision. Judgment scores, which ranged from -10 to +10 , were thus submitted to a 2 (Waiver decision) $\times 3$ (Condition) analysis of variance. There were no significant main effects for the waiver decision, $F(1,66)=1.31$, $p<.30, \eta_{\mathrm{p}}^{2}=.02$, or for the interrogation condition, $F(2,66)<1, \eta_{\mathrm{p}}^{2}=.02$. However, a nonsignificant interaction, $F(2,66)=2.31, p<.10, \eta_{\mathrm{p}}^{2}=.07$, showed that observers tended to see suspects as more innocent when they waived their rights than when they did not in the neutral $(M \mathrm{~s}=-2.86$ vs. $.90, p<.05)$ and sympathetic conditions $(M \mathrm{~s}=-3.67$ vs. $.33, p<.05)$ but not, understandably, in the hostile condition $(M \mathrm{~s}=$ 1.46 vs. $-1.27, n s)$.

\section{DISCUSSION}

In light of the persuasive interrogation techniques used by police-which, at times, are so coercive as to elicit confessions from innocent people-it is curious that a majority of citizens who find themselves under suspicion waive their Miranda rights to silence and an attorney. Through the use of a mock crime-and-investigation paradigm, we examined this general tendency, varied the actual guilt and innocence of the suspects, and tested the hypothesis that the waiver rate would be increased by a detective who uses sympathy and minimization and decreased by one who exhibits hostility and closed-mindedness.

The results of this experiment were revealing. Overall, $58 \%$ of all suspects tested waived their rights ( $63 \%$ in the neutral "baseline" condition), thus corroborating that the naturalistic observation of this tendency in the police station was also normative in our laboratory situation. There was no support for the hypothesis that sympathy and minimization would elevate the waiver rate-perhaps because both suspects and neutral observers saw the detective's positive overtures as disingenuous, as indicative of a presumption of guilt, and as strategically used to produce a waiver. However, the most striking effect was the highly significant decision-making difference between guilty and innocent suspects. Among those who had committed the mock theft, $64 \%$ invoked their rights, apparently believing that silence served their interests better than interrogation. Still, $36 \%$ of those who were guilty waived their rights, and they did so primarily for strategic reasons, so that the detective would not infer guilt from a lack of compliance. The data we obtained from observers suggests that this strategic concern is justified, that except when a suspect is confronted by an overtly hostile and closed-minded interrogator, people do infer guilt from his or her invocation of rights.

Among suspects who were innocent of the mock theft, in sharp contrast to those who were guilty, only $19 \%$ invoked their rights, with fully $81 \%$ agreeing to talk with the detective. This decision-making tendency appeared in all conditions and was so strong that $67 \%$ of innocent suspects signed the waiver even in the presence of a hostile and closed-minded interrogator who made it clear to participants that they had nothing to gain from denial—and where the danger was readily apparent to both suspects and observers. When they were later asked why, $72 \%$ of the innocents who 
waived their rights said they did so, quite simply, because they were innocent and had nothing to hide or fear.

In an observational study of 182 interrogations in California, Leo (1996) found that four out of five suspects waived their rights and that people without a criminal record were more likely to do so than those with prior felonies (see also Softley, 1980). In light of the known recidivism rates in criminal behavior, our results are consistent with-and shed light on-Leo's observations in suggesting that individuals who are truly innocent, because they naively believe in the power of their innocence to prevail, are most likely to waive their rights. Enabled by this waiver, innocent suspects increase the risk that they undergo coercive interrogations that set into motion various confirmation biases. In a recent experiment, Kassin, Goldstein, and Savitsky (2003) found that interrogators with guilty expectationsrelative to those with innocent expectations-asked more guilt-presumptive questions, used more techniques, and tried harder to elicit a confession, all leading observers to see the suspects as more defensive and guilty. In fact, the most pressurefilled sessions, by all accounts, occurred when guilty-expectation interrogators were paired with innocent suspects. Coupled with these findings, and the documented fact that innocent people at times confess to crimes they did not commit-as seen in many laboratory experiments (Horselenberg, Merckelbach, \& Josephs, 2003; Kassin \& Kiechel, 1996; Redlich \& Goodman, 2003) and DNA exoneration cases (e.g., Scheck, Neufeld, \& Dwyer, 2000)—our results suggest the ironic conclusion that during the early stages of a criminal investigation, innocence may put innocents at risk.

These results indicate that people have a naïve faith in the power of their own innocence to set them free. Conceptually, this effect may reflect a special instance of a generalized, and perhaps motivated, belief in a just world in which human beings "get what they deserve" and "deserve what they get" (Lerner, 1980). The effect may also be viewed as symptomatic of an "illusion of transparency," a tendency for people to overestimate the extent to which their own thoughts, emotions, and other inner states are detectable and knowable by others (Gilovich, Savitsky, \& Medvec, 1998; Miller \& McFarland, 1987). This illusion was evident in a recent study in which mock suspects erroneously assumed that their guilt or innocence would be judged accurately by the interrogator-and by others who would observe their denials (Kassin \& Fong, 1999).

From a practical and legal standpoint, this study suggests that Miranda warnings may not adequately protect from police authority the people who may need it most, those falsely accused of crimes they did not commit. With tragic results, this problem was evident in the classic case of Peter Reilly, an 18-year-old who confessed and internalized guilt for the murder of his mother after hours of suggestive interrogation. Solely on the basis of his confession, his confession, Reilly was prosecuted, convicted, and imprisoned until independent evidence later revealed that he could not have committed the murder. When asked in a recent interview why he did not invoke his Miranda rights, Reilly said, "My state of mind was that I hadn't done anything wrong and I felt that only a criminal really needed an attorney, and this was all going to come out in the wash" (Connery, 1996, p. 93). 
The present study introduced an experimental paradigm for the study of police interrogation and preinterrogation processes and exposed a possible limitation in Miranda to protect the accused. One might argue, despite necessary ethical constraints on the use of human participants, that this paradigm did not adequately simulate the high stakes experience that confronts people accused of actual crimesthus raising questions concerning external validity. Indeed, our overall waiver rate of $58 \%$ was lower than the $78 \%$ rate observed in actual practice (Leo, 1996). It is important to realize, however, that the absolute waiver rate across conditions is not relevant to our hypotheses concerning the relative differences among conditions. To be sure, the overall lower waiver rate may reflect the fact that our participants-compared to actual crime suspects-were educated college students, not at risk for prosecution, and under relatively little stress. We assume that there exist important differences between actual and mock suspects. Yet despite the ethicsdriven limitations inherent in our use of a mock crime, and despite the difference in overall waiver rates, participants were still highly and systematically influenced by their status as guilty or innocent - and the phenomenology that accompanies guilt and innocence. Limitations notwithstanding, our results were predictable and interpretable, they strongly supported our hypothesis, and they are consistent with Leo's naturalistic observations. Indeed, the effect of guilt and innocence on waiver decisions was of a magnitude that was both statistically and practically significant.

The decision to invoke or waive one's rights is such an important safeguard for people who stand accused that further research in both laboratory and naturalistic settings is needed to examine these decisions. Toward this end, additional studies should examine forensically relevant suspect characteristics. One possibly relevant factor is age, as juveniles may be more compliant in response to an investigator's waiver request than adults (Gudjonsson, 2003). Racial background, too, may prove to be a significant factor, particularly in urban settings where minorities often distrust local police (Taylor, 2002). Cultural differences should also be examined, particularly among Asian American immigrants whose upbringing places a premium on respect for authority. In Japan, for example, an astonishing $92 \%$ of all suspects capitulate during police interrogations and confess to the crime charged (Landers, 2000).

Further work is also needed to examine the situational influences on the Miranda decision, particularly the factors that impact upon perceived short-term and longterm benefits and costs. Among the possible influences in this regard are specific techniques used by police such as sympathy-and-minimization and the continuation of questioning "outside Miranda" (Weisselberg, 2001). Also potentially important are contextual factors such as the amount of in-custody time that has elapsed when a waiver is sought and time of day or night, as sleep loss increases compliance, suggestibility, and impulsivity in decision-making (Blagrove, 1996; Harrison \& Horne, 1996). In light of the surprising number of "actual innocence" cases emerging from recent DNA exonerations, a quarter of which contained confessions or admissions in evidence (Scheck et al., 2000), it is clear that more research is needed to understand this pivotal decision-making moment. 


\section{ACKNOWLEDGMENT}

This research was supported by funds generously provided by the Bronfman Science Center at Williams College.

\section{REFERENCES}

Blagrove, M. (1996). Effects of length of sleep deprivation on interrogative suggestibility. Journal of Experimental Psychology: Applied, 2, 48-59.

Cassell, P. G. (1996). Miranda's social costs: An empirical reassessment. Northwestern University Law Review, 90, 387-499.

Cassell, P. G., \& Fowles, R. (1998). Handcuffing the cops? A thirty-year perspective on Miranda's harmful effects on law enforcement. Stanford Law Review, 50, 1181-1191.

Clymer, S. D. (2002). Are police free to disregard Miranda? Yale Law Journal, 112, 447-552.

Connery, D. S. (Ed.). (1996). Convicting the innocent. Cambridge, MA: Brookline. Dickerson v. United States, 120 S. Ct. 2326 (2000).

Everington, C., \& Fulero, S. M. (1999). Competence to confess: Measuring understanding and suggestibility of defendants with mental retardation. Mental Retardation, 37, 212-220.

Fulero, S. M., \& Everington, C. (1995). Assessing competency to waive Miranda rights in defendants with mental retardation. Law and Human Behavior, 19, 533-543.

Gilovich, T., Savitsky, K., \& Medvec, V. H. (1998). The illusion of transparency: Biased assessments of others' ability to read one's emotional states. Journal of Personality and Social Psychology, 75, 332346.

Grisso, T. (1981). Juveniles' waiver of rights: Legal and psychological competence. New York: Plenum.

Grisso, T. (1998). Forensic evaluation of juveniles. Sarasota, FL: Professional Resource Press.

Gudjonsson, G. H. (2003). The psychology of interrogations and confessions. London: Wiley.

Harris v. New York, 401 U.S. 222 (1971).

Harrison, Y., \& Horne, J. A. (1996). Performance on a complex frontal lobe oriented task with "real-world" significance is impaired following sleep loss. Journal of Sleep Research, 5(Suppl. 1), 87.

Horselenberg, R., Merckelbach, H., \& Josephs, S. (2003). Individual differences And false confessions: A conceptual replication of Kassin and Kiechel (1996). Psychology, Crime and law, 9, $1-8$.

Kamisar, Y. (1995). On the "fruits" of Miranda violations, coerced confessions and compelled testimony. Michigan Law Review, 93, 929-1010.

Kassin, S. M. (1997). The psychology of confession evidence. American Psychologist, 52, 221-233.

Kassin, S. M., \& Fong, C. T. (1999). "I'm innocent!": Effects of training on judgments of truth \& deception in the interrogation room. Law and Human Behavior, 23, 499-516.

Kassin, S. M., Goldstein, C. C., \& Savitsky, K. (2003). Behavioral confirmation in the interrogation room: On the dangers of presuming guilt. Law and Human Behavior, 27, 187-203.

Kassin, S. M., \& Kiechel, K. L. (1996). The social psychology of false confessions: Compliance, internalization, and confabulation. Psychological Science, 7, 125-128.

Landers, P. (2000, October 6). A false confession jailed Mr. Yakushiji; then fate intervened. The Wall Street Journal, pp. A1, A7-A8.

Leo, R. A. (1996). Miranda's revenge: Police interrogation as a confidence game. Law and Society Review, 30, 259-288.

Leo, R. A. (2001). Questioning the relevance of Miranda in the twenty-first century. Michigan Law Review, 99, 1000-1029.

Leo, R. A., \& Ofshe, R. J. (1998). The consequences of false confessions: Deprivations of liberty and miscarriages of justice in the age of psychological interrogation. Journal of Criminal Law and Criminology, 88, 429-496.

Leo, R. A., \& Thomas, G. C. (1998). The Miranda debate: Law, justice, and policing. Boston: Northeastern University Press.

Leo, R. A., \& White, W. S. (1999). Adapting to Miranda: Modern interrogators' strategies for dealing with the obstacles posed. Minnesota Law Review, 84, 397-472.

Lerner, M. J. (1980). The belief in a just world. New York: Plenum.

Michigan v. Harvey, 494 U.S. 344 (1990).

Miller, D. T., \& McFarland, C. (1987). Pluralistic ignorance: When similarity is interpreted as dissimilarity. Journal of Personality and social Psychology, 53, 298-305. 
Miranda v. Arizona, 384 U.S. 336 (1966).

New York v. Quarles, 467 U.S. 649 (1984).

Oregon v. Hass, 420 U.S. 714 (1975).

Philipsborn, J. T. (2001, January/February). Interrogation tactics in the post-Dickerson era. The Champion, pp. 18-22, 75-78.

Radelet, M. L., Bedau, H. A., \& Putnam, C. E. (1992). In spite of innocence: Erroneous convictions in capital cases. Boston: Northeastern University Press.

Redlich, A. D., \& Goodman, G. S. (2003). Taking responsibility for an act not committed: The influence of age and suggestibility. Law and Human Behavior, 27, 141-156.

Scheck, B., Neufeld, P., \& Dwyer, J. (2000). Actual innocence: Five days to execution and other dispatches from the wrongly convicted. New York, NY: Doubleday.

Schulhofer, S. J. (1996). Miranda's practical effect: Substantial benefits and vanishingly small social costs. Northwestern University Law Review, 90, 500-564.

Softley, P. (1980). Police interrogation: An observational study in four police stations. London: Home Office Research Study, Royal Commission on Criminal Procedure Research Study.

Taylor, H. (2002, March 20). Nationwide love affair with NYPD has not changed nationwide attitudes toward the police. The Harris Poll \#13.

Weisselberg, C. D. (2001). In the stationhouse after Dickerson. Michigan Law Review, 99, 1121-1167.

White, W. S. (2001). Miranda's failure to restrain pernicious interrogation practices. Michigan Law Review, 99, 1211-1240.

Wrightsman, L. S., \& Kassin, S. M. (1993). Confessions in the courtroom. Newbury Park, CA: Sage.

Zamble, E., \& Quinsey, V. L. (1997). The criminal recidivism process. New York: Cambridge University Press.

Zimbardo, P. G. (1967, June). The psychology of police confessions. Psychology Today, 1, 17-20, 25-27. 